\title{
PERAN PANGKALAN PENDARATAN IKAN (PPI) CIKIDANG TERHADAP USAHA PERIKANAN DRIFT GILLNET
}

\section{The Role of Cikidang Fish Landing Base (PPI) in Drift Gillnet Fisheries Bussiness}

\author{
Oleh: \\ Irfan Syauqi ${ }^{1}$, Retno Muninggar ${ }^{1}$,Wawan Oktariza ${ }^{1}$ \\ ${ }^{1}$ Departemen Pemanfaatan Sumberdaya Perikanan, FPIK IPB University, Indonesia \\ Korespondensi: rmuninggar.ipb@gmail.com
}

\begin{abstract}
ABSTRAK
Peran Pangkalan Pendaratan Ikan (PPI) Cikidang telah diatur dalam Permen KP No 8 tahun 2012 tentang Kepelabuhanan Perikanan. Permasalahan penelitian adalah belum adanya informasi yang lengkap terkait peran PPI Cikidang terhadap usaha perikanan drift gillnet berdasarkan fungsi yang telah diatur dalam Permen KP No 8 ahun 2012. Disisi lain informasi terbaru terkait analisis usaha perikanan drift gillnet juga belum tersedia. Penelitian ini bertujuan untuk melakukan analisis peran PPI Cikidang terhadap usaha perikanan drift gillnet menggunakan pendekatan gap analysis dan melakukan analisis usaha perikanan drift gillnet. Penelitian menggunakan metode pengumpulan data purposive sampling dan simple random sampling. Hasil penelitian menunjukkan bahwa Peran PPI Cikidang terhadap kegiatan usaha perikanan drift gillnet berupa dukungan fasilitas pokok seperti breakwaterdan dermaga sudah cukup baik, namun ada beberapa aspek yang masih belum sesuai dengan fungsi PP/PPI pada Permen KP No.08 tahun 2012, yaitu aspek transportasi hasil tangkapan, pendataan hasil tangkapan dan administrasi. Analisis usaha perikanan drift gillnet secara rata-rata memiliki keuntungan sebesar Rp21.720.045 per tahun, nilai R/C rata-rata sebesar 1,37, nilai pengembalian investasi sebesar 0,37 dan waktu pengembalian investasi mencapai 2 tahun 2 bulan.
\end{abstract}

Kata kunci: analisis usaha, drift gillnet, gap analysis, PPI Cikidang

\section{ABSTRACT}

The role of the Cikidang Fish Landing Base (PPI) has been regulated in the decree of the minister of maritime affairs and fisheries number 8 year 2012 on FishingPort. The research problem is the lack of information related to the role and support of PPI Cikidang for the drift gillnet business based on the regulation. Beside that, updated information for the drift gillnet bussiness analysis is not available. The objective of this research was to analyze the role of PPI Cikidang for the drift gillnet bussiness using the gap analysis approach and do the analysis of drift gillnet bussiness. The research used purposive sampling and simple random sampling data collection methods. The results showed that the role of PPI Cikidang on the drift gillnet fisheries business activities was good enough especially for supporting basic facilities such as breakwater and jetty but there were some aspects is not according to the regulation, such as catch transportation, fisheries data collection and the administratios. An average profit of drift gillnet fisheries bussiness is $R p 21,720,045$ per year, an average $R / C$ value is 1.3 , the return on investment is 0.37 and the time to return on investment about 2 years and 2 months.

Key words: bussiness analysis, drift gillnet, gap analysis, PPI Cikidang 


\section{PENDAHULUAN}

Pangkalan Pendaratan Ikan (PPI) Cikidang terletak di Desa Babakan, Kecamatan Pangandaran. Tercatat sebanyak 108 Kelompok Usaha Bersama (KUB) nelayan yang berbasis di PPI Cikidang (DKP 2018). Banyaknya nelayan yang melakukan operasi penangkapan ikan dan berlabuh di PPI Cikidang, menjadikan PPI Cikidang sebagai pusat aktivitas perikanan tangkap di Kecamatan Pangandaran.

PPI Cikidang memiliki lima jenis unit usaha penangkapan ikan, yaitu jaring insang hanyut (drift gillnet), liong bun, rawai dasar, trammel net, dan vessel seine (PPI Cikidang 2018). Drift gillnet merupakan usaha penangkapan ikan yang terbanyak yaitu 450 unit dibandingkan usaha penangkapan lainnya yang hanya berjumlah 8-16 unit. Banyaknya unit penangkapan drift gillnet diduga karena adanya dukungan fasilitas dari pihak PPI Cikidang dan aspek teknis usaha penangkapan ikan drift gillnet seperti perahu, alat penangkapan ikan, metode penangkapan ikan, daerah penangkapan ikan dan musim penangkapan ikan.

Salah satu fungsi pelabuhan perikanan termasuk di dalamnya PPI (pelabuhan perikanan tipe D) adalah sebagai sarana pemerintahan dan sistem bisnis perikanan serta didalamnya terdapat fasilitas keselamatan pelayaran dan kegiatan penunjang perikanan (Permen KP No 8 tahun 2012). Disisi lain, kegiatan usaha perikanan drift gillnet akan menarik dari sisi investasi jika terdapat informasi yang lengkap mengenai kelayakan usaha termasuk di dalamnya keuntungan (profit) per tahun.

Permasalahan penelitian adalah belum adanya informasi yang lengkap terkait peran PPI Cikidang dalam mendukung usaha perikanan drift gillnet dan belum adanya analisis kelayakan usaha perikanan drift gillnet untuk saat ini. Kajian terakhir tentang analisis usaha drift gillnet di PPI Cikidang dilakukan oleh Gistindar (2006) dan Mardiana (2005).

Berdasarkan permasalahan yang ada maka penelitian ini dilakukan melalui pendekatan gap analysis untuk menjelaskan sejauh mana dukungan PPI terhadap usaha perikanan drift gillnet dan menggunakan pendekatan analisis usaha untuk mengetahui profit usaha, revenue cost ratio, payback period dan return of invesment. Tujuan penelitian adalah (1) melakukan analisis peran PPI Cikidang terhadap usaha perikanan drift gillnet, (2) melakukan analisis usaha perikanan drift gillnet.

\section{METODE PENELITIAN}

Penelitian dilakukan pada bulan Febuari hingga Oktober 2018 (musim peralihan barat). Lokasi penelitian bertempat di PPI Cikidang, Kecamatan Pangandaran, Kabupaten Pangandaran, Provinsi Jawa Barat. Penelitian menggunakan pendekatan case study dengan satuan kasus adalah usaha perikanan drift gillnet di PPI Cikidang. Pengumpulan data dilakukan melalui kegiatan wawancara dan pengamatan lapang. Untuk tujuan penelitian pertama, pemilihan responden dilakukan secara purposive (non probability), hal ini dikarenakan responden merupakan key informan yang memahami dengan mendalam objek penelitian. Responden tersebut adalah 3 orang pengelola PPI Cikidang. Sedangkan untuk tujuan kedua, penentuan responden dilakukan melalui simple random sampling (probability sampling) yaitu sebanyak 33 orang nelayan drift gillnet (jumlah ini merupakan 30\% dari populasi) berdasarkan Roscoe (1975).

Analisis data yang digunakan dalam penelitian ini: (1) Gap Analysis yaitu membandingkan antara peran exsisting PPI Cikidang terhadap usaha perikanan drift gillnet dengan peran yang seharusnya dilakukan berdasarkan Permen KP No 8 tahun 2012, (2) Analis usaha yang meliputi analisis penerimaan, analisis laba rugi, Analisis waktu pengembalian modal dan analisis return of investment.

1. Analisis penerimaan

Penerimaan $=$ Nilai produksi ikan $x$ Harga jual per $\mathrm{kg}$ ikan 
2. Analisis laba rugi

$\pi=T R-T C$

keterangan:

$\pi=$ Keuntungan usaha penangkapan ikan drift gillnet

TR = Total Revenue/Penerimaan usaha penangkapan ikan drift gillnet

$\mathrm{TC}=$ Total Cost $/$ Biaya usaha penangkapan ikan drift gillnet

3. Analisis imbangan penerimaan dan biaya

$R / C=\frac{T R}{T C}$

keterangan :

$\mathrm{TR}=$ Total Penerimaan per Tahun

$\mathrm{TC}=$ Total Biaya per Tahun

Analisis $R / C$ Ratio menggunakan tiga kriteria atau indikator yaitu pertama, perhitungan $\mathrm{R} / \mathrm{C}<1$ berarti usaha tidak menguntungkan. Penggunaan unit usaha drift gillnet lebih baik dihentikan. Kedua, hasil perhitungan $\mathrm{R} / \mathrm{C}=1$, usaha impas. Penggunaan unit usaha drift gillnet tetap dijalankan, namun tidak mendapatkan untung. Ketiga, perhitungan $\mathrm{R} / \mathrm{C}>1$, usaha menguntungkan.

4. Analisis waktu pengembalian modal (Payback period).

Payback period dapat dianalisis menggunakan per banding investasi dan keuntungan, melalui perbandingan biaya investasi dengan keuntungan yang diterima. Semakin besar keuntungan maka payback periode akan semakin cepat (Soekartawi 2016). Berikut disajikan rumus untuk menghitung waktu pengembalian modal usaha penangkapan jaring insang hanyut.

$P P=\frac{\text { Investasi }}{\text { Keuntungan }} x$ tahun

keterangan:

$\mathrm{PP}=$ payback period

5. Return of investment (ROI)

ROI merupakan nilai keuntungan usaha dibandingkan dengan modal (operasional) yang dikeluarkan saat usaha tersebut berjalan, sehingga dapat diketahui tingkat pengembalian investasi dari suatu usaha. Hal ini sesuai dengan teori yang disampaikan oleh Soekartawi (2016) bahwa ROI digunakan untuk mengetahui tingkat pengembalian investasi dari benefit (penerimaan) yang dihasilkan suatu usaha. Berikut disajikan rumus untuk menghitung tingkat pengembalian investasi usaha penangkapan jaring insang hanyut.

$R O I=\frac{\text { Laba Usaha }}{\text { Modal }}$

keterangan:

$\mathrm{ROI}=$ Return of Invesment

\section{HASIL DAN PEMBAHASAN}

PPI Cikidang saat ini dikelola langsung oleh UPT Pusat (Pemerintah Pusat) dan dalam proses pengajuan menjadi Pelabuhan Perikanan Nusantara (PPN). Luas area PPI Cikidang mencapai 5,4 ha. Terdapat fasilitas pelabuhan berupa dermaga, kolam pelabuhan yang terlindung dari gelombang, tempat pelelangan ikan, gudang es, dan kantor administrasi PPI Cikidang. Fasilitas-fasilitas utama pelabuhan seperti breakwater, dermaga, TPI dan kantor administrasi di PPI Cikidang berperan dalam mendukung aktivitas usaha penangkapan ikan drift gillnet, namun beberapa aspek PPI Cikidang belum 
melakukan fungsi pelayanannya secara lengkap. Hasil wawancara dengan pihak pengelola PPI dan TPI Cikidang, Pangandaran tertera pada Tabel 1 menggunakan pendekatan gap analysis.

Tabel 1 Gap analysis antara peran existing PPI Cikidang dengan peran yang diatur pada Permen KP No 12 tahun 2008

\begin{tabular}{|c|c|c|}
\hline Aspek & Dukungan exsisting & Dukungan seharusnya \\
\hline Break Water & $\begin{array}{l}\text { Break Water berfungsi } \\
\text { dengan baik, melindungi unit } \\
\text { penangkapan drift gillnet } \\
\text { dari terjangan gelombang }\end{array}$ & Sudah sesuai \\
\hline $\begin{array}{l}\text { Kolam } \\
\text { Pelabuhan/Dermaga }\end{array}$ & $\begin{array}{l}\text { Kolam pelabuhan cukup } \\
\text { dalam dan layak untuk } \\
\text { tambat labuh unit } \\
\text { penangkapan drift gillnet. }\end{array}$ & Sudah memadai \\
\hline Kantor Administrasi & $\begin{array}{l}\text { Kantor ini berfungsi dengan } \\
\text { baik, melayani kebutuhan- } \\
\text { kebutuhan administrasi unit } \\
\text { penangkapan drift gillnet } \\
\text { namun ada pendataan unit } \\
\text { usaha }\end{array}$ & $\begin{array}{l}\text { Pendataan unit usaha perlu dilakukan } \\
\text { untuk memudahkan PPI sebagai } \\
\text { pengelola pelabuhan dalam mengawasi } \\
\text { kegiatan usaha termasuk membuat } \\
\text { rencana pengembangan kawasan bisnis } \\
\text { dalam masterplan pelabuhan }\end{array}$ \\
\hline $\begin{array}{l}\text { Tempat Pelelangan } \\
\text { Ikan (TPI) }\end{array}$ & $\begin{array}{l}\text { TPI aktif melakukan } \\
\text { transaksi lelang. Namun, } \\
\text { transportasi dan sanitasi TPI } \\
\text { Cikidang masih belum } \\
\text { higienis dan belum } \\
\text { terlindung dari cahaya } \\
\text { matahari langsung. }\end{array}$ & $\begin{array}{l}\text { Transportasi untuk distribusi hasil } \\
\text { tangkapan harus mendukung cold chain } \\
\text { system sebagai upaya menjaga kualitas } \\
\text { hasil tangkapan }\end{array}$ \\
\hline $\begin{array}{l}\text { Pengumpulan data } \\
\text { tangkapan }\end{array}$ & $\begin{array}{l}\text { Pengumpulan data tangkapan } \\
\text { dilakukan oleh TPI, petugas } \\
\text { PPI tidak terlihat aktif dalam } \\
\text { pengumpulan data }\end{array}$ & $\begin{array}{l}\text { Salah satu fungsi pelabuhan perikanan } \\
\text { adalah pengumpulan data perikanan, } \\
\text { pihak PPI seharusnya membuat jadwal } \\
\text { agar setiap kapal bongkar di dermaga ada } \\
\text { petugas yang mencatat, sehingga data } \\
\text { perikanan di PPI Cikidang menjadi } \\
\text { lengkap dan valid. }\end{array}$ \\
\hline $\begin{array}{l}\text { Tempat pelaksanaan } \\
\text { penyuluhan }\end{array}$ & $\begin{array}{l}\text { Terdapat tempat khusus } \\
\text { untuk penyuluhan, namun } \\
\text { belum dilakukan pembinaan } \\
\text { rutin }\end{array}$ & $\begin{array}{l}\text { PPI membuat program pembinaan } \\
\text { kepada nelayan guna meningkatkan } \\
\text { kualitas dan produktivitas nelayan }\end{array}$ \\
\hline Kesyahbandaran & $\begin{array}{l}\text { Belum aktif, karena sebagian } \\
\text { besar nelayan menggunakan } \\
\text { perahu bukan kapal }\end{array}$ & $\begin{array}{l}\text { Kesyahbandaran menjalankan regulasi } \\
\text { untuk perizinan berlayar }\end{array}$ \\
\hline
\end{tabular}

Sumber: survei lapangan, 2018

Berdasarkan Tabel 1. dapat diketahui bahwa peran PPI Cikidang terkait fasilitas untuk melindungi kapal-kapal drift gillnet sudah memadai. Peran PPI dalam menyediakan alat transportasi untuk mengangkut hasil tangkapan dari dermaga ke TPI atau pasar ikan belum memenuhi standar rantai dingin, misal hasil tangkapan masih terpapar sinar matahari langsung. Kondisi ini seharusnya 
menjadi perhatian bagi pengelola PPI untuk melakukan perbaikan seperti penggantian alat angkut yang mampu menjaga kualitas ikan, seperti diangkut dengan mobil bak tertutup dan disimpan dalam drum atau kontainer berisi es. Selain itu, ketersediaan air bersih (Muninggar et al, 2017) dan pelabuhan perikanan yang memenuhi standar lingkungan (Muninggar et al, 2016) akan mendukung kegiatan penjaminan mutu hasil tangkapan yang didaratkan di pelabuhan perikanan. Peran PPI yang belum sesuai dengan peran pelabuhan dalam permen KP No 8 tahun 2012 adalah terkait fungsi pengumpulan data perikanan. Sebagai pusat pendaratan hasil tangkapan, tugas PPI adalah mencatat semua hasil tangkapan yang didaratkan. Data tersebut sangat penting untuk mengetahui volume produksi, produktivitas kapal, proyeksi hasil perikanan ke depan, informasi untuk perdagangan ikan dan informasi suplai ikan untuk para pedagang/pebisnis serta sebagai bahan pengembangan pelabuhan.

\section{Analisis Usaha Penangkapan Ikan Drift Gillnet}

Analisis usaha alat tangkap drift gillnet dihitung dalam periode satu tahun. Dalam penyajian hasil disajikan dalam tiga klaster yaitu terendah ( $\min )$, tertinggi (max), dan rataan. Penentuan terendah dan tertinggi didasarkan pada nelayan responden yang memiliki penerimaan terendah dan tertinggi.

\section{Biaya investasi}

Usaha penangkapan ikan drift gillnet di PPI Cikidang memiliki empat komponen investasi utama yaitu perahu, box es, mesin tempel dengan kekuatan 15 PK dan drift gillnet yang sudah dirakit dengan jumlah bervariasi antara 20 pieces sampai 60 pieces yang dimiliki oleh masing-masing unit operasi drift gillnet. Jumlah investasi unit per usaha penangkapan ikan drift gillnet tercantum dalam Tabel 2.

Tabel 2 Jumlah investasi usaha penangkapan ikan drift gillnet di PPI Cikidang tahun 2017-2018

\begin{tabular}{lrrr}
\hline \multicolumn{1}{c}{ Uraian } & \multicolumn{1}{c}{ Min (Rp) } & \multicolumn{1}{c}{ Max (Rp) } & \multicolumn{1}{c}{ Rata-rata (Rp) } \\
\hline Perahu/perahu & 4.000 .000 & 15.000 .000 & 12.696 .970 \\
Alat tangkap (drift & & 35.000 .000 & 16.436 .364 \\
gillnet) & 10.000 .000 & & \\
Mesin tempel 15 PK & 7.500 .000 & 25.000 .000 & 17.219 .697 \\
Cool box & 100.000 & 400.000 & 359.242 \\
\hline Total & 21.600 .000 & 75.400 .000 & 46.712 .273 \\
\hline
\end{tabular}

Sumber: survei lapangan, 2018

Biaya investasi rata-rata di PPI Cikidang masih lebih rendah dibandingkan dengan biaya investasi drift gillnet di PPS Cilacap (Hastuti 2013) dan juga di Kecamatan Toboali Kabupaten Bangka Selatan, Provinsi Bangka Belitung (Gerba et al, 2015). Hal tersebut diakibatkan oleh bahan alat tangkap yang digunakan dan besar GT kapal. Namun, secara waktu operasi tidak terlalu berbeda jauh antara operasi drift gillnet di PPI Cikidang dan drift gillnet di PPS Cilacap maupun di Kecamatan Toboali.

\section{Biaya tetap}

Biaya tetap yang dikeluarkan pada usaha alat tangkap drift gillnet adalah biaya penyusutan investasi dan biaya perawatan perahu, alat penangkapan ikan, dan mesin. Terkait biaya perizinan ditiadakan, hal ini disebabkan ukuran perahu tergolong kecil (kurang dari 5 GT) sehingga nelayan di PPI Cikidang tidak mengurus dan mengeluarkan biaya untuk perizinan. Masing-masing responden memiliki perbedaan biaya tetap yang dikeluarkan dan berikut adalah jumlah biaya tetap usaha penangkapan ikan drift gillnet berdasarkan jumlah penerimaan terkecil (min), terbesar (max), dan ratarata tercantum pada Tabel 3. 
Tabel 3 Jumlah biaya tetap usaha penangkapan ikan drift gillnet di PPI Cikidang tahun 2017-2018

\begin{tabular}{lrrr}
\hline \multicolumn{1}{c}{ Uraian } & \multicolumn{1}{c}{$\operatorname{Min}(\mathrm{Rp})$} & \multicolumn{1}{c}{ Rax $(\mathrm{Rp})$} & 4.707 .227 \\
\hline Penyusutan & 1.000 .000 & 500.000 & 946.969 \\
Perawatan perahu & 3.000 .000 & 1.500 .000 & 1.870 .000 \\
Perawatan mesin & 750.000 & 1.800 .000 & 2.416 .060 \\
Perawatan alat & 2.160 .000 & 7.540 .000 & \\
penangkapan ikan & & & 9.940 .257 \\
\hline \multicolumn{1}{c}{ Total } & 6.910 .000 & 11.340 .000 & \\
\hline
\end{tabular}

Sumber: survei lapangan, 2018

Hal yang menarik dari komposisi biaya tetap pada tabel 3 adalah tingginya biaya perawatan alat tangkap drift gillnet dialami oleh nelayan dengan jumlah penerimaan terbesar. Hal ini disebabkan oleh tingkat aktivitas dan jumlah hasil tangkapan yang lebih sering beroperasi yakni sebanyak 312 trip per tahun sehingga perawatan alat tangkap lebih sering dilakukan. Namun, hal tersebut sebanding dengan hasil yang diperoleh menjadi lebih banyak dibandingkan dengan nelayan lainya.

\section{Biaya variabel}

Biaya variabel yang dikeluarkan dalam setiap trip usaha penangkapan ikan $d r i f t$ gillnet terdiri dari biaya bahan bakar (BBM), biaya ransum (konsumsi nelayan yang melakukan trip), biaya es, dan biaya retribusi lelang tanpa penambahan biaya untuk upah ABK. Jenis BBM yang digunakan rata-rata menggunakan jenis pertalite. Persentase retribusi adalah 2\% per lelang. Tabel 4 adalah uraian dan jumlah biaya variabel usaha penangkapan ikan drift gillnet per trip di PPI Cikidang, Kecamatan Pangandaran, Kabupaten Pangandaran.

Tabel 4 Jumlah biaya variabel per trip usaha penangkapan ikan drift gillnet di PPI Cikidang tahun 2017-2018

\begin{tabular}{lrrr}
\hline \multicolumn{1}{c}{ Uraian } & Min $(\mathrm{Rp})$ & \multicolumn{1}{c}{$\operatorname{Max}(\mathrm{Rp})$} & \multicolumn{1}{c}{ Rata-rata $(\mathrm{Rp})$} \\
\hline BBM (14 liter pertalite) & 95.000 & 190.000 & 111.288 \\
Es Batu & 0 & 10.000 & 8.844 \\
Ransum (konsumsi saat trip) & 3.435 & 15.032 & 7.360 \\
Retribusi lelang & 50.000 & 100.000 & 78.636 \\
\hline Total Per Trip & 148.435 & 315.032 & 205.860 \\
\hline Total Per Tahun (207 trip) & 18.406 .000 & 98.290 .000 & 48.900 .060 \\
\hline
\end{tabular}

Sumber: survei lapangan, 2018

Biaya variabel dalam satu tahun usaha penangkapan ikan drift gillnet dapat dihitung dengan data rata-rata jumlah trip nelayan dikalikan dengan biaya variabel per trip. Berdasarkan hasil wawancara, nelayan PPI Cikidang rata-rata melakukan trip sebanyak 207 kali trip per tahunnya.

\section{Total pengeluaran}

Total pengeluaran yang dimaksud adalah seluruh biaya yang digunakan dalam menjalankan usaha alat tangkap drift gillnet di luar pengeluaran biaya investasi atau disebut sebagai biaya operasional. Biaya operasional memiliki komponen yaitu biaya variabel ditambahkan dengan biaya tetap sebagaimana tersaji pada Tabel 5. Total pengeluaran yang dimaksud adalah seluruh biaya yang digunakan dalam menjalankan usaha alat tangkap drift gillnet diluar pengeluaran biaya investasi atau disebut sebagai biaya operasional. Biaya operasional memiliki komponen yaitu biaya variabel ditambahkan dengan biaya tetap sebagaimana tersaji pada Tabel 5. 
Tabel 5 Jumlah pengeluaran usaha penangkapan ikan drift gillnet di PPI Cikidang tahun 2017-2018

\begin{tabular}{lrrr}
\hline \multicolumn{1}{c}{ Uraian } & \multicolumn{1}{c}{$\operatorname{Min}(\mathrm{Rp})$} & \multicolumn{1}{c}{$\operatorname{Max}(\mathrm{Rp})$} & \multicolumn{1}{c}{ Rata-rata $(\mathrm{Rp})$} \\
\hline Biaya tetap & 6.910 .000 & 11.340 .000 & 9.940 .257 \\
Biaya variable & 18.406 .000 & 98.900 .060 & 48.900 .060 \\
\hline Total & 25.316 .000 & 109.630 .000 & 58.094 .348 \\
\hline
\end{tabular}

Sumber: survei lapangan, 2018

Tabel 5 memperlihatkan adanya perbedaan yang cukup besar (sekitar 70\%) antara total biaya tetap terendah dan tertinggi. Hal ini disebabkan nelayan yang memiliki biaya tetap rendah menggunakan perahu, mesin, dan jaring yang tergolong baru serta kualitas terbaik sehingga dapat meminimalisir. Hal tersebut dapat meminimumkan pengeluaran untuk perawatan setelah melaut. Selain itu, jumlah dan jenis ransum per trip yang besar menyebabkan biaya yang dikeluarkan semakin besar.

\section{Total penerimaan}

Penerimaan yang didapat dari alat tangkap drift gillnet dasar merupakan hasil melaut dalam setahun. Jumlah trip nelayan berbeda-beda pada setiap musimnya. Pada musim puncak rata-rata nelayan melakukan trip sebanyak 27 kali per bulan. Semua nelayan akan libur melaut pada hari Jumat Kliwon. Pada musim biasa rata-rata nelayan melakukan 21 kali trip per bulan, dan pada musim paceklik rata-rata nelayan melakukan 6 kali trip per bulan. Hasil perhitungan penerimaan nelayan selama setahun periode 2017-2018 tersaji pada Tabel 6 .

Tabel 6 Jumlah penerimaan usaha penangkapan ikan drift gillnet di PPI Cikidang tahun 2017-2018

\begin{tabular}{lrrr}
\hline \multicolumn{1}{c}{ Uraian } & \multicolumn{1}{c}{ Min $(\mathrm{Rp})$} & \multicolumn{1}{c}{$\operatorname{Max}(\mathrm{Rp})$} & Rata-rata $(\mathrm{Rp})$ \\
\hline Musim puncak & 16.000 .000 & 180.000 .000 & 54.848 .485 \\
Musim biasa & 5.000 .000 & 50.000 .000 & 23.000 .000 \\
Musim paceklik & 300.000 & 4.500 .000 & 1.965 .909 \\
\hline Total & 21.300 .000 & 234.500 .000 & 79.814 .394 \\
\hline
\end{tabular}

Sumber: survei lapangan, 2018

Hal yang diduga mempengaruhi besarnya gap penerimaan usaha alat tangkap drift gillnet yaitu panjang alat tangkap yang digunakan, keahlian dan kedisiplinan ABK, dan waktu trip yang digunakan pada setiap trip. Panjang alat akan mendukung luasan sapuan alat tangkap, keahlian dan kedisiplinan yang dimiliki ABK handal akan mengarahkan operasi ke daerah potensial penangkapan ikan, serta waktu trip akan mempengaruhi usaha ABK dalam melakukan setting dalam setiap tripnya.

\section{Laba rugi}

Hasil analisis laba rugi menunjukkan bahwa nilai rata-rata laba/rugi bersih usaha penangkapan ikan drift gillnet di PPI Cikidang sebesar Rp21.720.045 dari total penerimaan rata-rata Rp79.814.394 dikurangi total pengeluaran Rp58.094.348. Adapun untuk nilai kerugian terbesar mencapai Rp4.016.000 per tahun dan nilai keuntungan tertinggi mencapai Rp124.870.000 per tahun. Hasil perhitungan laba/rugi usaha penangkapan ikan drift gillnet tersaji pada Tabel 7.

Tabel 7 Laba/Rugi usaha penangkapan ikan drift gillnet di PPI Cikidang tahun 2017-2018

\begin{tabular}{lccc}
\hline & Min $(\mathrm{Rp})$ & $\operatorname{Max}(\mathrm{Rp})$ & Rata-rata $(\mathrm{Rp})$ \\
\hline Laba & - & 124.870 .000 & 21.720 .045 \\
Rugi & 4.016 .000 & - & - \\
\hline
\end{tabular}

Sumber: survei lapangan, 2018

Hal ini tidak terlepas dari aspek teknis yang dimiliki oleh nelayan drift gillnet. Mulai perahu, alat tangkap, penentuan waktu operasi yang ujungnya akan berdampak pada efesiensi biaya operasi penangkapan ikan drift gillnet yang dikeluarkan. Efisiensi trip berpengaruh pada penambahan biaya 
variabel yang akan mengurangi penerimaan, hasil tangkapan berpengaruh pada penambahan penerimaan, dan biaya perawatan berpengaruh pada penambahan biaya pengeluaran sehingga mengurangi pendapatan.

\section{Rasio penerimaan dan biaya $(\mathrm{R} / \mathrm{C})$}

Analisis R/C usaha penangkapan ikan drift gillnet di PPI Cikidang Kabupaten Pangandaran dihitung dengan cara jumlah penerimaan rata-rata (Rp79.814.393) dibagi pengeluaran rata-rata (Rp58.094.348) sehingga didapat nilai R/C 1,37. Nilai R/C terkecil adalah 0.84 didapat dari penerimaan Rp21.300.000 dibagi total pengeluaran sebesar Rp25.316.000, dan nilai $\mathrm{R} / \mathrm{C}$ terbesar yaitu 2,13 didapat dari total penerimaan sebesar Rp234.500.000 dibagi total pengeluaran Rp109.630.000. Hasil perhitungan disajikan pada Tabel 8.

Tabel 8 Rasio penerimaan dan biaya (R/C) usaha penangkapan ikan drift gillnet di PPI Cikidang tahun 2017-2018

\begin{tabular}{lccc}
\hline & $\operatorname{Min}(\mathrm{Rp})$ & $\operatorname{Max}(\mathrm{Rp})$ & Rata-rata $(\mathrm{Rp})$ \\
\hline Nilai R/C & 0,84 & 2,13 & 1,37 \\
\hline
\end{tabular}

Sumber: survei lapangan, 2018

Hasil perhitungan diatas dapat diinterpretasikan bahwa tidak semua usaha drift gillnet di PPI Cikidang, Kecamatan Pangandaran, Kabupaten Pangandaran memiliki keuntungan. Dari 33 nelayan responden terdapat 18 unit usaha drift gillnet yang rasio penerimaan di atas 1 , dan 15 unit lainya di bawah 1 . Nilai R/C terkecil sebesar 0,84 . Hal ini menunjukkan bahwa sebanyak $54 \%$ unit usaha drift gillnet di PPI Cikidang memiliki keuntungan. Namun, 46\% unit usaha drift gillnet lainya tidak bisa menutupi biaya operasional yang dikeluarkan atau secara akumulasi merugi. Upaya yang dapat menyebabkan banyak nelayan merugi adalah tidak adanya pengaturan trip dan jumlah panjang jaring yang digunakan (Setiawati 2015).

\section{Payback period}

Payback period (PP) merupakan teknik penilaian terhadap jangka waktu (periode) pengembalian investasi suatu usaha. Payback period dapat dilihat dari perhitungan kas bersih (proced) yang diperoleh setiap tahun (Jakfar dan Kasmir 2010). Pada penelitian ini objek analisisnya adalah unit usaha penangkapan ikan drift gillnet, dengan tidak ada penambahan unsur pajak dalam perhitungan biaya penyusutan. Dengan asumsi kas setiap tahun sama, waktu pengembalian investasi rata-rata unit usaha alat tangkap drift gillnet di PPI Cikidang tersaji pada Tabel 9.

Tabel 9 Periode pengembalian biaya investasi usaha penangkapan ikan drift gillnet di PPI Cikidang tahun 2017-2018

\begin{tabular}{crrrr}
\hline $\begin{array}{c}\text { Tahun } \\
\text { ke- }\end{array}$ & Laba bersih (Rp) & $\begin{array}{c}\text { Biaya investasi } \\
(\mathrm{Rp})\end{array}$ & Sisa pengembalian (Rp) & $\begin{array}{c}\text { Payback Period } \\
(\mathrm{PP})\end{array}$ \\
\hline 1 & 21.720 .045 & 46.712 .273 & -24.992 .228 & \\
2 & 21.720 .045 & - & -3.272 .183 & 2 tahun \\
3 & 21.720 .045 & - & 18.447 .862 & 2 bulan \\
\hline
\end{tabular}

Sumber: survei lapangan, 2018

Berdasarkan tabel di atas, diketahui waktu yang digunakan untuk pengembalian investasi ratarata 2 tahun dan 2 bulan. Waktu pengembalian akan berbanding terbalik dengan jumlah keuntungan. Semakin besar keuntungan maka waktu pengembalian akan lebih cepat.

\section{Return of Invesment (ROI)}

ROI digunakan untuk mengetahui tingkat pengembalian investasi dari benefit (penerimaan) yang dihasilkan suatu usaha. Kegiatan usaha unit penangkapan drift gillnet potensial dikembangkan jika hasil ROI $>1$. Berdasarkan hasil wawancara dengan responden, nilai ROI unit usaha drift gillnet 
di PPI Cikidang Kabupaten Pangandaran dapat dihitung perbandingan laba dan modal usaha yaitu Rp21.720.045 (laba/tahun) dibagi Rp58.094.348 (biaya operasional/tahun). Oleh sebab itu didapat nilai ROI sebesar 0,37. Nilai ROI 0,37 menunjukan bahwa tingkat pengembalian investasi usaha drift gillnet di PPI Cikidang Kabupaten Pangandaran masih rendah (Harjanti 2012). Kondisi tersebut dapat diantisipasi dengan cara mengurangi jumlah trip pada musim paceklik dan sedang, menambah jumlah drift gillnet, melakukan perawatan mesin baru secara berkala, dan melakukan perawatan rutin terhadap setiap aspek teknis usaha penangkapan ikan drift gillnet sehingga dapat menekan pengeluaran.

\section{KESIMPULAN DAN SARAN}

Peran PPI Cikidang terhadap kegiatan usaha perikanan drift gillnet berupa dukungan fasilitas pokok seperti breakwaterdan dermaga sudah cukup baik, namun ada beberapa aspek yang masih belum sesuai dengan fungsi PP/PPI pada Permen KP No.08 tahun 2012 tentang kepelabuhanan perikanan, yaitu aspek transportasi hasil tangkapan, pendataan hasil tangkapan dan administrasi. Selain itu, analisis usaha perikanan drift gillnet secara rata-rata memiliki keuntungan sebesar Rp21.720.045 per tahun, nilai $\mathrm{R} / \mathrm{C}$ rata-rata sebesar 1,37, nilai pengembalian investasi (ROI) masih rendah yaitu sebesar 0,37 dan waktu pengembalian investasi mencapai 2 tahun 2 bulan.

\section{DAFTAR PUSTAKA}

[DKP] Dinas Kelautan dan Perikanan. 2018. Data alat tangkap. Pangandaran (ID): Dinas Kelautan Perikanan Kabupaten Pangandaran.

Gerba SV, Agustriani F, Isnaini. 2015. Analisis finansial penangkapan ikan dengan alat tangkap drift gillnet di Kecamatan Toboali Kabupaten Bangka Selatan Bangka Belitung. Maspari Journal. 7(2):19-24

Gistindar G. 2006. Analisis kelayakan usaha penambahan investasi pada aktivitas penyediaan sarana penangkapan ikan di KUD Minasari Kecamatan Pangandaran, Kabupaten Ciamis [skripsi]. Bogor (ID): Institut Pertanian Bogor.

Harjanti R, Pramonowibowo, Hapsari TD. 2012. Analisis musim penangkapan dan tingkat pemanfaatan ikan layur (Trichiurus sp) di perairan Palabuhanratu, Sukabumi, Jawa Barat. Journal of Fisheries Resources Utilization Management and Technolog y.1(1):55-66.

Hastuti. 2013. Analisis teknis dan ekonomis usaha perikanan tangkap drift gill net di Pelabuhan Perikanan Samudera Cilacap. Journal of Fisheries Resources Utilization Management and Technology. 2(2):102-112.

Jakfar dan Kasmir. 2009. Studi Kelayakan Bisnis Edisi 2. Jakarta (ID): Kencana Prenada Media Group.

[KKP] Kementrian Kelautan dan Perikanan. 2012. Keputusan Menteri Kelautan Perikanan nomor 08 tahun 2012 tentang kepelabuhanan perikanan. Jakarta (ID): KKP RI.

Mardiana H. 2005. Tingkat pendapatan usaha nelayan gillnet di Desa Pangandaran Kecamatan Pangandaran, Kabupaten Ciamis, Jawa Barat [skripsi]. Bogor (ID): Institut Pertanian Bogor.

Muninggar R, Lubis E, Iskandar BH, Haluan J. 2016. Aspek lingkungan signifikan di Pelabuhan Perikanan Samudera Nizam Zachman Jakarta. Marine Fisheries: Journal of Marine Fisheries Technology and Management: 7(2):203-210.

Muninggar R, Lubis E, Iskandar BH, Haluan J. 2017. Water quality status in the largest Indonesian fishingport. Advance Environmental Sciences Bioflux. 9(3):173-182. 
[PPI Cikidang] Pangkalan Pendaratan Ikan Cikidang. 2018. Raman Nelayan. Pangandaran (ID): PPI Cikidang.

Roscoe JT. (1975). Fundamental research statistics for the behavioural sciences. (2nd ed.) New York: Holt Rinehart \& Winston.

Setiawati B, Wijayanto D, Pramonowibowo. 2015. Analisis faktor produksi hasil tangkapan ikan kembung (Rastrelliger sp) pada alat tangkap drift gill net di Kabupaten Ketapang, Kalimantan Barat. Journal of Fisheries Resources Utilization Management and Technology. 4 (2):40-48.

Soekartawi. 2016. Analisis Usahatani. Jakarta: UI Press. 